\title{
Effect of tropical millipede Rhinocricus botocudus in the degradation and maturity of coffee residues
}

\author{
Victor Maurício da Silva ${ }^{1} \mathbb{D}$, Renato Ribeiro Passos ${ }^{2}$, Ericka Broetto Marin ${ }^{1}$, Eduardo de Sá Mendonça²
}

${ }^{1}$ Universidade Federal do Espírito Santo/UFES, Vitória, ES, Brasil

${ }^{2}$ Universidade Federal do Espírito Santo/UFES, Departamento de Agronomia, Centro de Ciências Agrárias, Alegre, ES, Brasil

Contact authors: victormaurciodasilva@gmail.com; renatoribeiropassos@hotmail.com; erickabrma@gmail.com; eduardo.mendonca@ufes.br

Received in June 22, 2021 and approved in November 19, 2021

\section{ABSTRACT}

In Brazil, approximately 3 tons of dry mass per hectare of coffee residues (CR), formed by leaves and branches $<5$ mm in diameter, were accumulated around the crops in the last harvests of the semi-mechanized crops. Thus, the production of substrates and organic fertilizers from the bioconversion of residues of coffee activity is an important theme in Brazil and in the world. The objective of the study was to investigate the effectiveness of the tropical millipede Rhinocricus botocudus on the degradation and maturity of coffee residues (CR). The presence or absence of $R$. botocudus were tested in five sampling times $(0,30,60,90$, and 120 days) with three replicates $(n=3)$. The analyzed variables were: total $C$ and $N$ contents, lignin, cellulose, soluble $C$ and $\mathrm{N}$, soluble polyphenols, $\mathrm{C}$ of humic substances, and infrared analysis of humic acid (HA) and fulvic acid (FA). At the final incubation stage (120 days), the lowest values of cellulose, cellulose/lignin, and polyphenols occurred with $R$. botocudus. Infrared analysis of HA demonstrated that readily biodegradable structures, such as alcohols and short chain aliphatic molecules, were decomposed over time, consequently reflecting the increase of aromatic structures of greater stability. Compared to the control, these changes in HA were more evident in the presence of $R$. botocudus. The results of the present study suggest that this millipede species modify the dynamics of degradation and humification of CR by accelerating the maturity of this residue.

Key words: Cellulose; humic substances; lignin.

\section{Introduction}

Brazil, the second largest producer of Robusta coffee (Coffea canephora) in the world, produces a large amount of waste from the harvest and processing of its fruits. Approximately 3 tons of dry mass (DM) per hectare of coffee residues (CR), formed by leaves and branches $<5 \mathrm{~mm}$ in diameter, basis of calculations in Bragança et al. (2010), accumulated around crops in the last harvests of the semiharvests mechanized. Faced with this high quantity of $\mathrm{CR}$, its disposal has become an important economic, social, and environmental problem in Brazil and in the world.

$\mathrm{CR}$ is a recalcitrant material, with low degradability, when compared to other organic wastes (Tortosa et al., 2012, Subhedar; Gogate, 2014, Yan et al., 2015) and it presents some disadvantages for its direct use in soil management or other agronomic purposes: (1) high levels of phytotoxic polyphenols; (2) high levels of recalcitrant structural components (e.g., lignin and cellulose); and (3) low density (dry basis) that will affect its use. Due to the high levels of organic matter and some nutrients (e.g., K, Ca), CR could be recycled as a promising alternative to produced organic substrates and fertilizers.

Millipedes (Diplopoda class) are terrestrial arthropods that can be used to optimize the bioconversion of residues in organic fertilizers (Karthigeyan; Alagesan, 2011; Ramanathan; Alagesan, 2012; Sridhar; Ambarish, 2013; Antunes et al., 2016). Most species are detritivorous and preferentially feed on plant residues (litter fall) with contrasting chemical compositions (Semenyuk et al., 2011; Ambarish; Sridhar, 2013; Svyrydchenko; Brygadyrenko, 2014). These animals, fragment the organic residues mechanically when feeding, increasing their surface area and, consequently, favor the growth and biochemical microbial performance (Rawlins et al., 2006). The excreta are constituted of undigested plant tissues, mineral particles, microorganisms, and have higher $\mathrm{pH}$ values, as well as higher water retention capacity, when compared to structured litter fall (Tajovský et al., 1992).

The Rhinocricus botocudus (Rhinocricidae) species is relatively small compared to its congeners (53-80 $\mathrm{mm}$ and 8.0$10.3 \mathrm{~mm}$ ) (Schubart, 1962) and are widely found in the State's Robusta coffee plantations of Espirito Santo, Brazil, where they feed on coffee litterfall (personal observation). The population density in these crops ranged from 0 to 60 individuals per $\mathrm{m}^{2}$, presenting a maximum dry matter mass of $36 \mathrm{~g} \mathrm{~m}^{-2}$. Under laboratory conditions, CR consumption of dry matter $190 \mathrm{mg}$ individual ${ }^{-1}$ day $^{-1}$ was observed. The consumption observed in the laboratory is considered high for the tropical millipede species (Bianchi; Correia, 2007), and this can be explained by the high calcium content in the $\mathrm{CR}$, associated to the high demand that they have for this chemical element for the production of the calcified exoskeleton (Hopkin; Read, 1992; Kalisz; Powell, 2003). However, despite the great potential and importance, there is still little literature on decomposition with tropical millipede species.

The CR is a residue with high lignin and cellulose contents. Lignin is a very complex three-dimensional molecule and is the most recalcitrant structural component of the plant 
cell wall (Taherzadeh; Karimi, 2008). Cellulose is a polymer of glucose formed by units of cellobiose (Delmer; Amor, 1995). In general, higher content of the lignin-cellulose complex in organic waste results in slower degradation by microbial extracellular enzymes (Buswell; Odier, 1995; Parthasarathi et al., 2016). Due to the strong interaction between microorganisms and millipedes, these invertebrates influence the degradation dynamics of structural components in organic wastes; however, there are no studies on the influence of tropical millipedes on the decomposition of these components in CR.

In the case of humification processes in residues, humic substances (HS) are important components of organic matter that directly and indirectly favor the growth of plants (Stevenson 1994; Nardi et al., 2002; Plaza et al., 2008). The HS are formed mainly by humic acids (HA) and fulvic acids (FA), and these fractions are used to study the dynamics of HS transformation in controlled processes of waste decomposition (Dias et al., 2010; Antunes et al., 2015). Fourier transformed infrared spectroscopy (FTIR) is a widely used analytical method to monitor transformations in functional HA and FA groups in composting and vermicomposting processes (Baddi et al., 2004; Huang et al., 2006; Zhou et al., 2014; Antunes et al., 2015); however, FTIR studies on HS fractions in waste decomposition processes with tropical millipedes are limited.

Additionally, the maturity of organic matter can be tested by means of the study of certain variables considered as indicators in decomposition processes, e.g. C content (soluble and total) and soluble polyphenols (Bernal et al., 1998; Castaldi et al., 2008; Dias et al., 2010; Antil et al., 2013); however, these should be considered in conjunction with other variables, such as the HA/FA ratio and spectroscopic analyses.

The objective of the study was to investigate the effectiveness of the tropical millipede $R$. botocudus on the degradation and maturity of CR. The hypothesis of this study is that in 120 days of incubation, the millipede $R$. botocudus optimizes the decomposition and maturity of $\mathrm{CR}$, promoting greater degradation of recalcitrant components of OM (e.g., lignin, cellulose, polyphenols) and also increasing the HA/FA ratio and aromatic compounds of greater stability within HA and FA.

\section{Materials and Methods}

\subsection{Incubation with Rhinocricus botocudus}

The experiment was conducted under laboratory conditions with adults of $R$. botocudus. In July 2015, millipedes were collected for the installation of the Robusta coffee crop experiment in the municipality of Linhares, state of Espirito Santo, Brazil (19 23 '28 “'S, 40 04' 20” W). The region has tropical Aw climate, presenting a rainy season in the summer and dry in the winter, and it has an average annual rainfall of
$1160 \mathrm{~mm}$ and average temperature of $25^{\circ} \mathrm{C}$. The soil of the locality was classified as a Oxisol (USDA, 2013).

The coffee residues (CR) used comprised the leaves and branches $<5 \mathrm{~mm}$ in diameter. This residue was collected 30 days after its pruning for the semi-mechanized harvest of Robusta coffee in Linhares-ES, Brazil (19¹5'67' S, $\left.40^{\circ} 01^{\prime} 93^{\prime \prime} \mathrm{W}\right)$. The physicochemical characteristics of the CR used are present in Table 1.

Table 1: Physical-chemical characterization of the coffee residue used in the study.

\begin{tabular}{cc}
\hline Attributes & Coffee Residue \\
\hline Moisture $(\%)$ & 10.6 \\
$\mathrm{pH}$ & 7.6 \\
Density (dry mass) & 0.1 \\
$\mathrm{EC}\left(\mathrm{dS} \mathrm{m}^{-1}\right)$ & 1.4 \\
Phosphorus $\left(\mathrm{g} \mathrm{kg}^{-1}\right)$ & 3.5 \\
Potassium $\left(\mathrm{g} \mathrm{kg}^{-1}\right)$ & 14.3 \\
Calcium $\left(\mathrm{g} \mathrm{kg}^{-1}\right)$ & 30.6 \\
Magnesium $\left(\mathrm{g} \mathrm{kg}^{-1}\right)$ & 6.6 \\
\hline
\end{tabular}

The containers, consisting of $48.7 \times 25.7 \times 18.9 \mathrm{~cm}$ styrofoam boxes, were filled with a layer of $12.6 \mathrm{~L}$ of CR. The volume of material was measured by means of the scales, and for this purpose, its density was previously determined. Density was performed by adding CR in a container with a known volume and measured on a scale, then this weight was divided by the volume. To reduce the sampling error, ten repetitions were performed.

The experiment was set up in a completely randomized design $(2 \times 5$ factorial scheme and two conditions of invertebrates with and without millipedes), using five sampling intervals ( 0 , $30,60,90$, and 120 days) and three replicates $(n=3)$. For the millipede level (MILI), the containers received $25 \mathrm{~g}$ of fresh adult weight of $R$. botocudus (approx. $16 \pm 1$ individuals or $10 \mathrm{~g}$ dry mass). This amount was determined based on a preliminary test of CR consumption by $R$. botocudus and according to Karthigeyan and Alagesan (2011). The control level (CONT) consisted of containers incubated without $R$. botocudus.

The containers were covered with black porous fabric, and the experiment was carried out in the dark in an environment with controlled temperature at $25 \pm 2^{\circ} \mathrm{C}$. The humidity was determined and adjusted to $50 \%$ throughout the experiment (dry basis), but oscillations were checked. This moisture was corrected by means of mathematical calculations from samples taken every 15 days (approx $2 \mathrm{~g}$ of fresh material) and drying in an oven. The containers were moistened daily with distilled water. The samples were collected at initial time, 30, 60, 90, and 120 days of incubation. 


\subsection{Extraction of humic substances}

Humic substances (HS) were extracted according to procedures adapted from Huang et al. (2006) and Zhou et al. (2014). Samples previously dried in air were extracted with $\mathrm{NaOH}$ $\left(0.1 \mathrm{~mol} \mathrm{~L}^{-1}\right)$ with solid:extraction solution ratio of $1: 10(\mathrm{~m} / \mathrm{v}$, dry mass basis) after shaking for 24 hours. The supernatant, which contains the humic substances, was collected after centrifugation at $8000 \mathrm{~g}$ for 15 minutes. This procedure was repeated twice, and for each sample, the extracts were combined in the same vessel. The $\mathrm{pH}$ of the extract was adjusted to 7.0 with $\mathrm{HCl}\left(0.5 \mathrm{~mol} \mathrm{~L}^{-1}\right)$, and the organic $\mathrm{C}$ analysis of $\mathrm{HS}$ was performed according to Walkley and Black (1934). The separation of humic acid (HA) and fulvic acid (FA) was performed as follows: the $\mathrm{pH}$ of the extract was adjusted to 1.0 with $\mathrm{HCl}\left(3 \mathrm{~mol} \mathrm{~L}^{-1}\right)$ and was kept for 12 hours at a temperature of $4{ }^{\circ} \mathrm{C}$. Subsequently, it was centrifuged at $8000 \mathrm{~g}$ for 15 minutes. The precipitate contained the HA, while the supernatant contained the FA. The FA was separated in another vessel, and the $\mathrm{HA}$ was washed with $\mathrm{HCl}\left(0.05 \mathrm{~mol} \mathrm{~L}^{-1}\right)$ twice. The $\mathrm{pH}$ of both fractions was adjusted to 7.0, and organic $\mathrm{C}$ was determined according to Walkley and Black (1934). Remaining HA and FA samples were lyophilized, obtaining a solid mass and used for FTIR analysis.

\subsection{Fourier transform infrared spectroscopy (FTIR)}

FTIR analysis was performed for the 0,60 , and 120 days periods of incubation. This analysis was performed by transmission in a sample diluted in potassium bromide $(\mathrm{KBr})$. The pellets were prepared by adding $180 \mathrm{mg} \mathrm{KBr}$ to $4 \mathrm{mg}$ of lyophilized HA or FA. Subsequently, they were ground in a mortar until the mixture became homogeneous. This mixture was placed on a conventional pastillator $(13 \mathrm{~mm}$ in diameter) and pressed at $10 \mathrm{t} \mathrm{cm}^{-2}$. Samples were scanned in a range between 4000 and $500 \mathrm{~cm}^{-1}$ using Tensor 27 equipment (Bruker), equipped with Opus 6.5 software.

\subsection{Organic matter (OM), lignin, cellulose, total organic C (TOC), and total (TN)}

In pre-dried samples from all stages of incubation, $\mathrm{OM}$ content was determined in a muffler oven at $550^{\circ} \mathrm{C}$. Analyses of TOC and TN were done with an Organic Elemental Analyzer, Flash 2000 (Thermo Scientific).

The lignin and cellulose contents were determined by the acid detergent fiber (ADF) method of Van Soest and Wine (1968), which is based on the separation of the different constitutive fractions of the material using specific reagents called detergents. $\mathrm{H}_{2} \mathrm{SO}_{4}$ and cetyltrimethyl ammonium bromide (CTAB) were used to eliminate starch and nitrogen compounds, thus leaving lignin, cellulose, and ash. The cellulose was removed by $\mathrm{H}_{2} \mathrm{SO}_{4}(72 \%)$, and the lignin was determined by weight difference, subtracting the ash by burning at $550^{\circ} \mathrm{C}$ in a muffler oven (Anderson; Ingram, 1996).

\subsection{C soluble in water (CSW), $\mathrm{N}$ soluble in water}

\section{(NS) and soluble polyphenols (SP)}

For the determination of CSW, NS and SP, samples from all stages of incubation were previously oven dried $\left(65^{\circ} \mathrm{C}\right)$ and ground in a mill $(<2 \mathrm{~mm})$. For the determination of CSW and NS, extraction with distilled water (ratio $1: 10, \mathrm{~m} / \mathrm{v}$ ) was performed by shaking for 24 hours. The extracts were centrifuged at the speed of $8000 \mathrm{rpm}$, for 10 minutes and then filtered. The content of CSW was determined by oxidation with potassium dichromate $\left(0.33 \mathrm{~mol} \mathrm{~L}^{-1}\right)$ and titration with ferrous sulfate heptahydrate (0.4 $\mathrm{mol} \mathrm{L}^{-1}$ ) and diphenylamine indicator (Ciavatta et al., 1991). The NS content was determined by the Kjeldhal method (adapted from Bremner; Mulvaney, 1982; Tedesco, 1995).

For determination of SP, the extraction was performed from $100 \mathrm{mg}$ of sample mixed with $40 \mathrm{~mL}$ of methanol (50\%) kept at $77-80{ }^{\circ} \mathrm{C}$ for one hour. The final concentration was determined colorimetrically $(760 \mathrm{~nm})$ using the Folin-Denis reagent and tannic acid as standard (Anderson; Ingram, 1996).

\subsection{Statistical analyses}

The analyses were performed in three replicates $(\mathrm{n}=$ 3 ), and mean values and standard errors were presented. Data were submitted to analysis of variance (ANOVA), and the LSD test $(p \leq 0.10)$ was used to determine significant differences between treatments. Statistics was based on Sisvar software.

\section{Results}

\subsection{Decomposition of OM, TOC, TN, lignin and cellulose during $\mathrm{CR}$ incubation}

During CR incubation, the OM contents decreased ( $\mathrm{p} \leq$ 0.01 ), and there was no difference between treatments (Table 2). It is noteworthy that, in both treatments, the decreases were low, around $4 \%$ of the initial value. TOC levels decreased $(p \leq 0.001)$ throughout the incubation period, while $\mathrm{N}$ levels increased ( $\mathrm{p}$ $\leq 0.05$ ) (Table 2). There was no difference between treatments for TOC and TN contents $(\mathrm{p}>0.05)$. During the initial stage of decomposition (0-30 days), TOC levels decreased in proportions from 3.5 to $4.3 \%$, and these proportions generally decreased over the incubation period.

The reduction in TOC content associated with the increase in $\mathrm{TN}$ contents resulted in a decrease $(\mathrm{p} \leq 0.01)$ in the $\mathrm{C} / \mathrm{N}$ ratio in both treatments. At the end of incubation (120 days), there was no difference for the $\mathrm{C} / \mathrm{N}$ ratio between treatments. During this period, values of $\mathrm{C} / \mathrm{N}$ ratio of 19 and 18 occurred for control and treatment with $R$. botocudus, respectively.

The decomposition of the lignin contents of $\mathrm{CR}$ is presented in Table 3. Time effects were observed in both treatments ( $\mathrm{p} \leq 0.0001)$, as there were increases of 4 and $21 \%$ at the end of incubation (120 days) for the treatment control 
and with $R$. botocudus, respectively. At the 90 days sampling, there were differences $(\mathrm{p} \leq 0.001)$ with higher levels of lignin in the treatment with $R$. botocudus compared to the control.

For the cellulose contents, time effects occurred in both treatments $(\mathrm{p} \leq 0.0001)$ (Table 3$)$. For the control, these contents increased during the incubation. For the treatment with $R$. botocudus, a reduction was observed for the third month of incubation, and at 120 days, a reduction of $5 \%$ was observed in relation to the initial value. At 90 days, the treatment with $R$. botocudus had lower levels of cellulose compared to the control.

The CR initial cellulose/lignin ratio was 0.80 , and at the end of incubation (120 days), values of 0.92 and 0.63 occurred for the control and $R$. botocudus treatments, respectively (Table 3). At 90 days of incubation, smaller values for this ratio ( $\mathrm{p} \leq 0.0001)$ were found in the presence of $R$. botocudus in comparison to the control.

\subsection{Decomposition of soluble C in water (CSW), $\mathrm{C} / \mathrm{N}_{\text {Soluble, }}$ and soluble polyphenols}

In both treatments, the levels of CSW decreased ( $p$ $\leq 0.0001)$ throughout the incubation period, and the highest reductions occurred in the first 30 days (Figure 1a). After 60 days, the treatment with $R$. botocudus presented lower ( $\mathrm{p} \leq$ 0.10) CSW content compared to the control. At the end of incubation (120 days), the mean contents were 5.5 and $4.2 \mathrm{~g}$ $\mathrm{kg}^{-1}$ for the control treatments and with millipedes, respectively.
There was a significant reduction $(p \leq 0.0001)$ of the soluble $\mathrm{C} / \mathrm{N}$ ratio over time for both treatments (Figure $1 \mathrm{~b}$ ). At the end of incubation (120 days), the treatment with $R$. botocudus presented the lowest $(\mathrm{p} \leq 0.06)$ soluble $\mathrm{C} / \mathrm{N}$ ratio, with a value of 10.5 .

The decomposition of the soluble polyphenol contents of the CR showed a pattern similar to the CSW, characterized by a considerable decrease during the first 30 days of the incubation (Figure 1a). After 60 days, the treatment with $R$. botocudus presented lower $(\mathrm{p} \leq 0.001)$ polyphenols content than the control.

\subsection{Humic substances (HS)}

In both treatments, the $\mathrm{C}$ of HS decreased $(\mathrm{p} \leq 0.0001)$ for the incubation period (Figure $2 \mathrm{a}$ ). After 30 days, the $\mathrm{C}$ of HS was lower $(\mathrm{p} \leq 0.001)$ in the treatment with $R$. botocudus compared to the control. The proportions of reductions were 30 and $52 \%$ for the control and millipede treatment, respectively.

The increase in C levels of HA, associated with the strong reduction of $\mathrm{C}$ of the FA, resulted in an increase ( $p$ $\leq 0.0001$ ) in the HA/FA ratio in both treatments throughout the incubation (Figure 2b). After 60 days, treatment with $R$. botocudus showed a higher $(\mathrm{p} \leq 0.05)$ HA/FA ratio compared to control. At 120 days, the treatment with millipedes presented an HA/FA ratio of 2.9, while the control presented a value of 2.2 .

Table 2: Mean values of OM, TOC, and TN in different incubation times of CR with and without $R$. botocudus.

\begin{tabular}{ccccccccc}
\hline \multirow{2}{*}{ Time (days) } & \multicolumn{2}{c}{ OM $(\%)$} & \multicolumn{2}{c}{ TOC $\left(\mathrm{g} \mathrm{kg}^{-1}\right)$} & \multicolumn{2}{c}{ TN $\left(\mathrm{g} \mathrm{kg}^{-1}\right)$} & \multicolumn{2}{c}{ C/N Ratio } \\
\cline { 2 - 8 } & CONT & MILL & CONT & MILL & CONT & MILL & CONT & MILL \\
\hline 0 & $91 \pm 0.2$ & $91 \pm 0.2$ & $428 \pm 1.3$ & $428 \pm 1.3$ & $22 \pm 0.4$ & $22 \pm 0.4$ & $23 \pm 0.5$ & $23 \pm 0.5$ \\
30 & $90 \pm 0.1$ & $90 \pm 0.1$ & $410 \pm 3.7$ & $413 \pm 0.3$ & $23 \pm 0.9$ & $23 \pm 0.3$ & $21 \pm 0.9$ & $21 \pm 0.2$ \\
60 & $89 \pm 0.6$ & $89 \pm 0.4$ & $419 \pm 1.2$ & $421 \pm 5.4$ & $25 \pm 0.4$ & $21 \pm 0.9$ & $20 \pm 0.3$ & $24 \pm 1.3$ \\
90 & $87 \pm 1.5$ & $88 \pm 0.4$ & $405 \pm 5.2$ & $408 \pm 4.0$ & $25 \pm 0.8$ & $24 \pm 0.7$ & $19 \pm 0.7$ & $20 \pm 0.7$ \\
120 & $87 \pm 0.5$ & $88 \pm 0.5$ & $404 \pm 3.4$ & $406 \pm 2.5$ & $26 \pm 0.7$ & $27 \pm 1.6$ & $19 \pm 0.7$ & $18 \pm 1.0$ \\
\hline
\end{tabular}

OM: Organic matter; TOC: Total organic carbon; TN: Total nitrogen; CR: Coffee residues. Analysis of variance (ANOVA) and the LSD test ( $p \leq 0.10)$ was used to determine significant differences between treatments.

Table 3: Cellulose, lignin, and cellulose/lignin ratio in different incubation times of $\mathrm{CR}$ with and without $R$. botocudus.

\begin{tabular}{|c|c|c|c|c|c|c|}
\hline \multirow{2}{*}{ Time (days) } & \multicolumn{2}{|c|}{ Cellulose $\left(\mathrm{g} \mathrm{kg}^{-1}\right)$} & \multicolumn{2}{|c|}{ Lignin $\left(\mathrm{g} \mathrm{kg}^{-1}\right)$} & \multicolumn{2}{|c|}{ Cellulose/lignin } \\
\hline & CONT & MILL & CONT & MILL & CONT & MILL \\
\hline 0 & $304 \pm 2.6$ & $304 \pm 2.6$ & $382 \pm 5.4$ & $382 \pm 5.4$ & $0.80 \pm 0.007$ & $0.80 \pm 0.007$ \\
\hline 30 & $293 \pm 0.2$ & $299 \pm 5.1$ & $431 \pm 3.0$ & $434 \pm 4.4$ & $0.68 \pm 0.005$ & $0.69 \pm 0.025$ \\
\hline 60 & $306 \pm 7.1$ & $348 \pm 7.7$ & $429 \pm 0.4$ & $414 \pm 1.5$ & $0.71 \pm 0.016$ & $0.84 \pm 0.010$ \\
\hline 90 & $359 \pm 5.5$ & $326 \pm 5.1$ & $423 \pm 4.5$ & $458 \pm 4.0$ & $0.85 \pm 0.009$ & $0.71 \pm 0.015$ \\
\hline 120 & $366 \pm 1.4$ & $290 \pm 5.0$ & $398 \pm 4.3$ & $462 \pm 2.4$ & $0.92 \pm 0.021$ & $0.63 \pm 0.010$ \\
\hline
\end{tabular}

CR: Coffee residues. Analysis of variance (ANOVA) and the LSD test $(p \leq 0.10)$ was used to determine significant differences between treatments. 

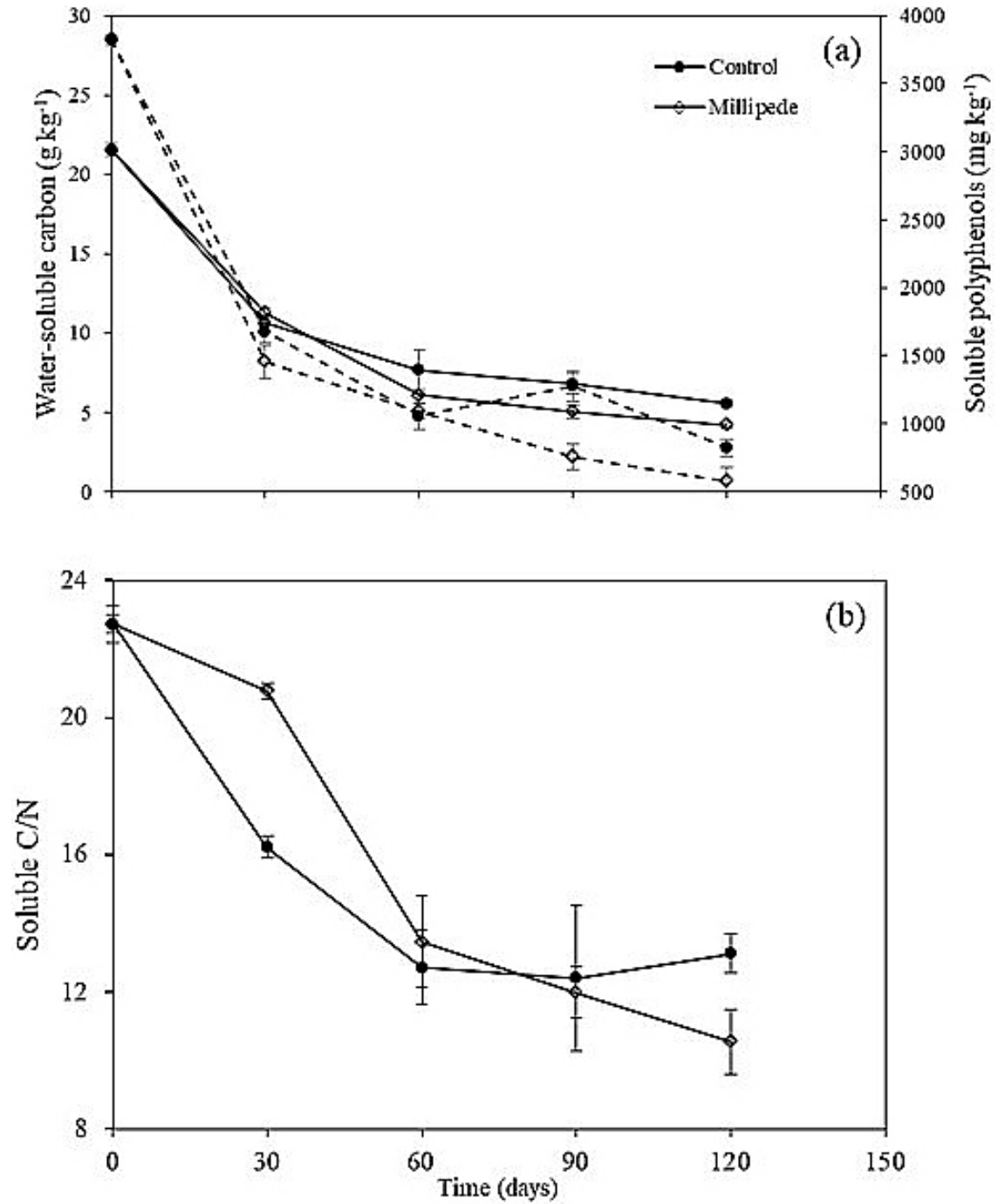

Figure 1: (a) Changes for soluble carbon in water (CSW) - continuous line and soluble polyphenols (SP) - dashed line; and (b) changes in soluble $\mathrm{C} / \mathrm{N}$ ratio during $\mathrm{CR}$ decomposition under the influence of the millipede $R$. botocudus. Analysis of variance (ANOVA) and the LSD test ( $\leq 0.10)$ was used to determine significant differences between treatments.

\subsection{Fourier transform infrared spectroscopy (FTIR)}

\subsubsection{Humic acid (HA) bands}

The changes along the incubation for HA are presented in Figure 3. The main absorbance bands with their respective assignments are presented in Table 4. In both treatments, there were decreased in intensity over time for the following absorbance bands: wide bands ranging from $3408-3404 \mathrm{~cm}^{-1}$ (O-H stretch); peaks at $2926 \mathrm{~cm}^{-1}$ (aliphatic C-H groups); and small peaks of $1122-1119 \mathrm{~cm}^{-1}$ (aliphatic $\mathrm{CH}_{2}$ groups). On the other hand, intensity increases occurred for acute peaks of $837-834 \mathrm{~cm}^{-1}$ ( $\mathrm{CH}$ of aromatic compounds). All these changes were, in general, more evident in the presence of $R$. botocudus compared to the control treatment, and most of these changes were noticed as early as at 60 days.

In addition, strong absorption occurred around 1000$999 \mathrm{~cm}^{-1}$ (C-O polysaccharides). For this interval, increases occurred throughout the incubation for the control treatment. In the treatment with $R$. botocudus, these peaks had a strong increase at 60 days, followed by reduction at 120 days.

\subsubsection{Fulvic acid (FA) bands}

The FA spectra are shown in Figure 4 in control and during different stages of incubation of coffee residue with millipedes $R$. botocudus (initial time, 60 and 120 days). The absorbance bands with their assignments are shown in Table 5. In both treatments, there were decreases of intensity over time for the following absorbance bands: peaks at $2940 \mathrm{~cm}^{-1}$ (aliphatic C-H groups); 1609-1602 $\mathrm{cm}^{-1}$ bands ( $\mathrm{N}-\mathrm{H}$ strain $+\mathrm{C}=\mathrm{N}$ stretch, amide II); and small peaks of 1123-1121 $\mathrm{cm}^{-1}$ (aliphatic $\mathrm{CH}_{2}$ groups). Only for peaks at $2940 \mathrm{~cm}^{-1}$ and $1609 \mathrm{~cm}^{-1}$, the intensity reductions were more evident in the presence of $R$. botocudus, and, throughout the incubation, the other bands showed similar tendencies between treatments. 

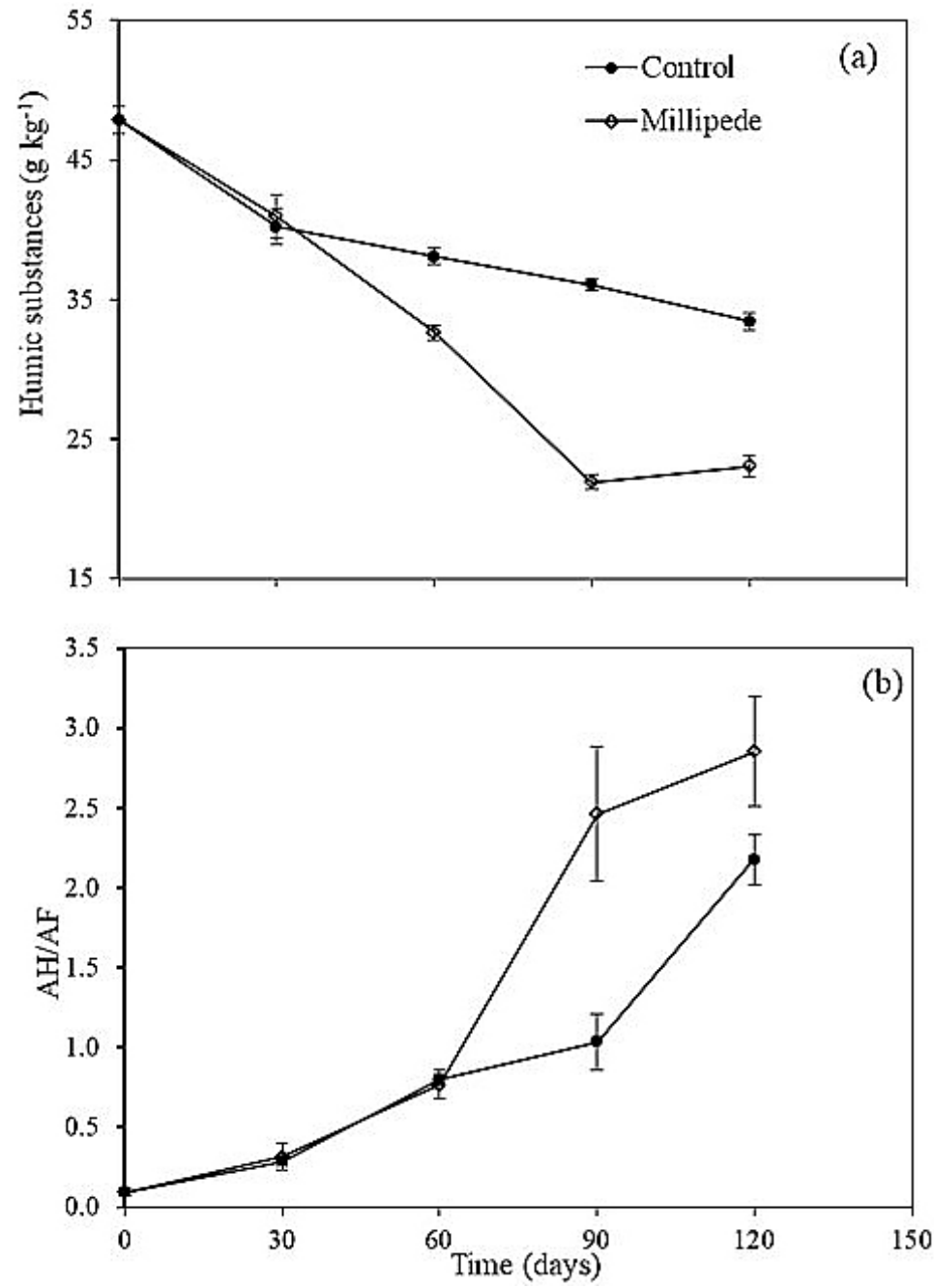

Figure 2: (a) Changes in the $C$ content of the extractable humic substances and (b) in the HA/FA ratio during CR decomposition under the influence of the millipede $R$. botocudus. Analysis of variance (ANOVA) and the LSD test $(p \leq 0.10)$ was used to determine significant differences between treatments.
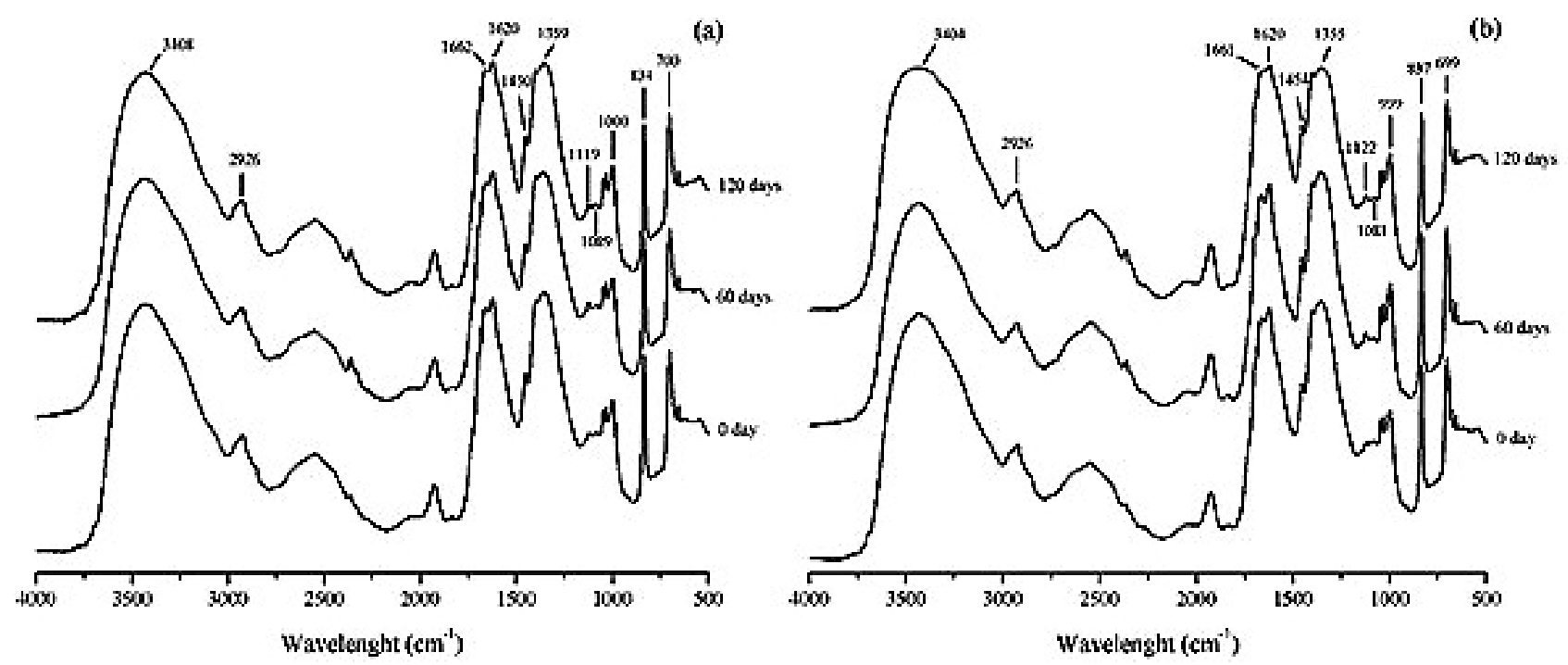

Figure 3: FTIR images of humic acid during different stages of incubation of coffee residue (CR): control (a); and with millipedes R. botocudus (b). 
Table 4: Main bands of humic acid in FTIR spectra

\begin{tabular}{cc}
\hline Wavelength $\left(\mathbf{c m}^{-1}\right)$ & Assignment \\
\hline $\begin{array}{c}3408-3404 \\
2926\end{array}$ & $\begin{array}{r}\text { O-H stretch of hydrogen bond in carboxylic groups, Alcohols and phenols } \\
\text { aliphatic } \mathrm{C}-\mathrm{H} \text { stretch; methyl and methylene groups; lipids and fats }\end{array}$ \\
$1662-1661$ & $\mathrm{C}=$ Ostretchofamide (amide I), $\mathrm{C}=\mathrm{O}$ of quinone and, or $\mathrm{C}=\mathrm{O}$ bound to the $\mathrm{H}$ of conjugated ketones \\
1620 & $\mathrm{C}=\mathrm{C}$ stretch of aromatic compounds \\
$1454-1450$ & Aliphatic $\mathrm{C}-\mathrm{H}$ stretch and of methyl groups \\
$1359-1355$ & OH deformation and C-O stretch of phenolic $\mathrm{OH}, \mathrm{C}-\mathrm{H}$ deformation of $\mathrm{CH}_{2}$ and $\mathrm{CH}_{3}$ \\
$1122-1119$ & symmetrical bonds of aliphatic $\mathrm{CH}_{2}$ and $\mathrm{OH}$ \\
$1089-1081$ & $\mathrm{C}-\mathrm{O}$ stretch of polysaccharides \\
$1000-999$ & $\mathrm{C}-\mathrm{O}$ stretch of carbohydrates and polysaccharides \\
$837-834$ & $\mathrm{C}-\mathrm{H}$ in aromatic compounds \\
\hline
\end{tabular}
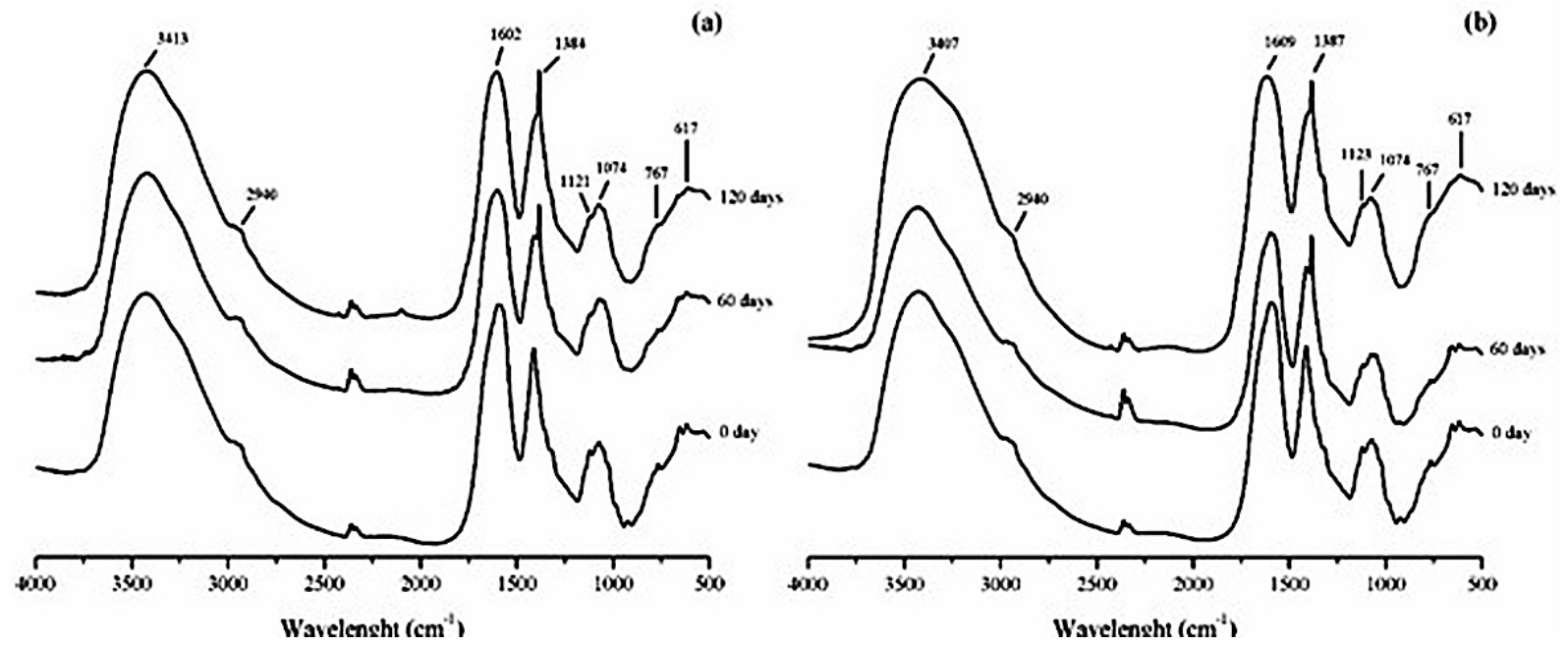

Figure 4: FTIR images of fulvic acid during different stages of incubation of coffee residue: control (a); and with millipedes R. botocudus (b).

Table 5: Main bands of fulvic acid in FTIR spectra.

\begin{tabular}{cc}
\hline Wavelength $\left(\mathbf{c m}^{-1}\right)$ & Assignment \\
\hline $3413-3407$ & O-H stretch of hydrogen bond in carboxylic groups, Alcohols and phenols \\
2940 & aliphatic $\mathrm{C}-\mathrm{H}$ stretch; lipids \\
$1609-1602$ & Stretching of the aromatic $\mathrm{C}=\mathrm{C}$ bond sand, or $\mathrm{N}-\mathrm{H}$ deformation $+\mathrm{C}=\mathrm{N}$ stretch (amide II) \\
$1387-1384$ & $\mathrm{OH}$ deformation and $\mathrm{C}=\mathrm{O}$ stretching of phenolic groups, $\mathrm{C}-\mathrm{H}$ deformation of $\mathrm{CH}_{2}$ and $\mathrm{CH}_{3}$, stretching $\mathrm{COO}-^{-}$ \\
$1123-1121$ & $\mathrm{C}-\mathrm{O}$ stretch of polysaccharides \\
767 & $\mathrm{CH}$ deformation of aromatic groups \\
617 & $\mathrm{C}-\mathrm{C}$ mono substituent on aromatic rings \\
\hline
\end{tabular}

\section{Discussion}

\subsection{Decomposition of OM, TOC, TN, lignin, and cellulose during $\mathrm{CR}$ incubation}

The decreases in OM and TOC contents are considered low for controlled decomposition processes, as compared to works that used other types of residues (Bernal et al., 1998; Grigatti et al., 2004). In the case of lignocellulosic residues such as $\mathrm{CR}$, the decreases of $\mathrm{OM}$ and $\mathrm{C}$ are lower when compared to other labile and biodegradable residues (Dias et al., 2010). In a study of organic composting with lignocellulosic residue of grape marc, no significant changes 
were observed in the contents of OM and C, over the 150 days of incubation (Paradelo et al., 2013). In the current study, the low decomposition level of the organic matter may be due to the high proportion of lignin from $\mathrm{CR}$, which confers high resistance to enzymatic degradation.

The highest losses of TOC in the initial stage of incubation (0-30 days) should be related to the utilization of easily biodegradable organic matter by microorganisms (Huang et al., 2006). To the extent that readily biodegradable materials were used, degradation rates became slower, since more complex organic compounds (e.g., lignin, cellulose) could have become source energy and nutrition sources for microbial activity (Yamadav; Kawase, 2006; Zhou et al., 2014). The organic C losses and consequent reductions in the mass of $\mathrm{CR}$, promoted increases in total $\mathrm{N}$ contents, due to a possible concentration effect of this chemical element (Dias et al., 2010).

The $\mathrm{C} / \mathrm{N}$ ratio is one of the main indicators used to evaluate the maturity of organic residues in decomposition processes (Bernal et al., 1998; Fernández-Gómez et al., 2010; Domínguez; Gómez-Brandón, 2013; Sridhar; Ambarish, 2013). In the present study, $\mathrm{C} / \mathrm{N}$ ratio was less than 20 , in both treatments, at 120 days. It is indicative that the substrates were stable and mature (Hirai et al., 1983).

The increase that occurred for lignin contents at 120 days suggests a concentration effect of this macromolecule for the incubation period used in the present study (four months). Lignocellulosic residue decomposition (grape marc) increased lignin contents up to the fourth month, as degradation has started at fifth month of incubation (Paradelo et al., 2013).

The highest increases in lignin contents with the presence of $R$. botocudus after 90 days showed that this species optimized the concentration effect of this macromolecule. At 120 days, CR density was 0.14 and $0.26 \mathrm{Mg} \mathrm{m}^{-3}$ for control and treatment with $R$. botocudus, respectively. This result showed that, during the incubation, the consumption of leaves mainly compacted to $\mathrm{CR}$ biomass as excreta, increasing its density considerably (2.7 times the initial value).

The reduction in cellulose contents and the lower values of $R$. botocudus at 90 days showed the potential of this millipede species for the degradation of CR structural compounds. The degradation of structural components (e.g., cellulose, hemicellulose) of organic residues by millipedes are mediated by symbiotic microorganisms and/or directly by the metabolism of these macroinvertebrates (Coûteaux et al., 2002). Taylor and Crawford (1982) observed that cellulose degradation, in the midgut of millipedes, was done by populations of aerobic microorganisms. On the other hand, after bacteriostatic treatment, enzymatic activity (e.g., xylanase, cellulase) was verified in the intestine of the millipede Glomeris hexasticha, indicating that these enzymes can be produced directly by these invertebrates (Urbasek; Tajovský, 1991).
The cellulose/lignin ratio is an accurate indicator of maturity in controlled processes of organic waste decomposition (Komilis; Ham 2003; Paradelo et al., 2013). The value of 0.80 is used as the threshold value to distinguish between mature and immature residues, and in immature residues, this value may be above 4.0 (Paradelo et al., 2013). The lowest values in the presence of $R$. botocudus in the final stages of the incubation can be explained by the greater degradation of cellulose after 90 days associated with increases in lignin contents. These results indicated that these myriapods optimized CR maturity through the degradation of structural compounds of this residue.

\subsection{Decomposition of C soluble in water (CSW), $\mathrm{C} / \mathrm{N}_{\text {Soluble }}$ and soluble polyphenols}

The decrease in CSW and C/N solubility agreed with other studies that used organic residues with physico-chemical characteristics, with or without edaphic macroinvertebrates (Charest et al., 2004; Castaldi et al., 2008; Mupondi et al., 2011; Alidadi et al., 2016). During the early stages of decomposition, bioavailable molecules (e.g., carbohydrates, peptides and others) are at higher concentrations in the immature residues (Zmora-Nahum et al., 2005; Alidadi et al., 2016). As these molecules are degraded biochemically by the microorganisms, the CSW is rapidly reduced (Zhou et al., 2014).

The lowest levels of CSW at treatment with millipedes after 60 days could be explained by changes in the biochemical composition that occurred when $R$. botocudus consumed the CR. Comparisons of the chemical composition of oak residue (Quercus robur) and excrement of Glomeris marginata millipede demonstrated that this millipede, when feeding on this residue, used only easily degradable soluble compounds, such as carbohydrates and short chain peptides (Rawlins et al., 2006). Most of the degradation of these compounds occurred with the help of microorganisms that inhabit the millipede gut (Rawlins et al., 2007). These investigations supported the results of the current study, suggesting that $R$. botocudus supported the decomposition and maturity of CR.

The CSW levels at 120 days for control and millipedes treatment $\left(<6 \mathrm{~g} \mathrm{~kg}^{-1}\right)$ were below $10 \mathrm{~g} \mathrm{~kg}^{-1}$, suggesting that in both treatments, the $\mathrm{CR}$ reached maturity during this study (Hue; Liu, 1995). However, the $\mathrm{C} / \mathrm{N}_{\text {soluble }}$ value of 10.5 presented for the $R$. botocudus treatment was above the ideal value (between 5-6) for maturity according to Chanyasak and Kubota (1981), suggesting a longer experiment time for this variable. The coffee residue presents high level of recalcitrance (lignin contents) when compared to others, such as animal manures (poultry and cattle), oil extraction residue, rice straw, and others (Tortosa et al., 2012; Subhedar; Gogate, 2014; Yan et al., 2015). According to the results observed, it is noteworthy that this higher recalcitrance of this compound 
is mainly due to its lignified branches that make up 38\% of the dry mass, which are not entirely degraded by millipedes This shows that, through the selective consumption of leaves, this species optimized the concentration of the lignified branches of coffee trees. Therefore, if the use of the generated feedstock is for agronomic purposes (e.g., substrates for seedlings), it is recommended to separate these remaining branches by sifting.

The highest reductions in soluble polyphenol contents in the first 30 days mean that the most soluble fraction was used as the $\mathrm{C}$ source during the first weeks of decomposition of the $\mathrm{CR}$, which corresponds to the period of greatest microbial activity (Dias et al., 2010). The lower concentration after 60 days in the treatment with $R$. botocudus compared to the control suggested that this millipede species, by endosymbiotic microorganisms enzyme producers, optimized degradation of polyphenols from $\mathrm{CR}$.

Leaves of coffee trees, which make up about $62 \%$ of the dry mass of CR, have high levels of polyphenols (Farah; Donangelo, 2006; Salgado et al., 2008). Most of the polyphenol molecules are considered phytotoxic (Domínguez et al., 2014). In degradation processes (eg, composting, vermicomposting), the degradation of phytotoxic compounds is considered as a maturity indicator ( $\mathrm{Wu}$ et al., 2000; Domínguez et al., 2014). Therefore, the greater degradation of polyphenols by $R$. botocudus, especially after 60 days of incubation, showe that this species of millipede had the potential to optimize CR maturity.

\subsection{Humic substances (HS)}

The HA/FA ratio is widely used to describe the dynamics of HA and FA transformation, as well as the maturity in controlled processes of organic waste decomposition (Dev; Antil, 2011; Zhou et al., 2014). The CR had relatively high amounts of fibrous structural components, such as lignin. This macromolecule provides stable phenolic compounds that act as the base nucleus in humification processes (Stevenson, 1994; Lopez et al., 2002). This explained the increasing formation of HA and the consequent increase in the HA/FA ratio throughout the $\mathrm{CR}$ incubation.

Additionally, HA/FA ratio increase may be related to the strong decrease in $\mathrm{C}$ of the FA fraction. This decrease suggested that microorganisms used these acids (organic compounds of lower molecular weight) for their metabolism and conversion of organic matter into HA (Zhou et al., 2014). FA decrease in parallel to the increasing formation of HA (higher molecular weight compounds) are indicative of the maturity of CR. It is noteworthy that this phenomenon was improved in the presence of $R$. botocudus, which explains the greater reduction of $\mathrm{C}$ of HS after 30 days and the greater increase of HA/FA ratio after 60 days with this macroinvertebrate.

\subsection{Fourier transform infrared spectroscopy (FTIR)}

For HA decreased in intensity during incubation for $\mathrm{OH}$ groups in carboxylic acids (3408-3404 $\left.\mathrm{cm}^{-1}\right)$, aliphatic $\mathrm{CH}$ groups $\left(2926 \mathrm{~cm}^{-1}\right)$, and aliphatic $\mathrm{CH} 2$ groups (1122-1119 $\mathrm{cm}^{-1}$ ) suggested gradual degradation of the peptides, lipids, and polysaccharides of the CR (Inbar et al., 1990; Stevenson, 1994; Huang et al., 2006). However, the increase in the intensity of $\mathrm{CH}$ groups of aromatic compounds $\left(837-834 \mathrm{~cm}^{-1}\right)$, possibly occurred due increases in aromatic structures of higher stability in organic matter (Gerasimovwicz; Bayler, 1985; Huang et al., 2006; Zhou et al., 2014). In general, these changes more evident in the treatment with $R$. botocudus demonstrated that this species optimized the humification of CR. In this sense, changes occurring as early as 60 days (e.g., peaks around $837 \mathrm{~cm}^{-1}$ ) suggested that these myriapods had the potential to accelerate humification and maturity of CR.

The CR comprised high contents of lignin, cellulose, and other structural components, since this residue is formed by leaves and branches of coffee trees with high fiber matter. This could justifiys the appearance of peaks with wavelengths of 1000-999 $\mathrm{cm}^{-1}$ (C-O groups of carbohydrates and polysaccharides) (Zhou et al., 2014). In addition, the reduction of intensity at that peak at 120 days in the treatment with $R$. botocudus supported the results for reduction in cellulose contents and reinforced the potential of this species in the degradation of structural components of CR.

The FTIR results for FA confirmed those found for HA, showing that unstable aliphatic structures (e.g., $2940 \mathrm{~cm}^{-1}$, 1123-1121 $\mathrm{cm}^{-1}$ ) were biodegraded throughout the incubation. However, compared to HA, the FA spectra were less sensitive between treatments.

\section{Conclusions}

At the end of the incubation, the lowest values of cellulose, cellulose/lignin, and soluble polyphenols in the treatment with $R$. botocudus, highlight the potential of this species for the degradation of structural and phenolic compounds of CR.

FTIR analysis of HA of the coffee residue showed that short chain aliphatic molecules were decomposed throughout the incubation, proportionally reflecting the increase of aromatic structures of greater stability, these changes were more evident in the presence of $R$. botocudus. In addition to this, this species promoted greater increases in the HA/ FA ratio. These results suggest that this species alters the humification dynamics of CR by accelerating its maturity. 


\section{Acknowledgments}

The authors wish to acknowledge the support of the Fundação de Amparo à Pesquisa e Inovação do Espírito Santo - FAPES, in granting a post-graduate scholarship to the first author. Also to the professors of the Laboratory of Soils of the Universidade Estadual do Norte Fluminense - UENF to the support for conducting the analyzes of lignin, cellulose and polyphenols of the present study.

\section{References}

ALIDADI, H. et al. Waste recycling by vermicomposting: Maturity and quality assessment via dehydrogenase enzyme activity, lignin, water soluble carbon, nitrogen, phosphorous and other indicators. Journal of Environmental Management, 182:134-140, 2016.

AMBARISH, C. N.; SRIDHAR, K. R. Production and quality of pill-millipede manure: a microcosm study. Agricultural Research, 2:258-264, 2013.

ANDERSON, J. D; INGRAM, J. S. I. Tropical soil biology and fertility: A handbook of methods. 2 nd ed. Wallingford (UK): CAB International. 1996. 221p.

ANTIL, R. S. et al. Evaluation of maturity and stability parameters of composts prepared from organic wastes and their response to wheat. Waste Biomass Valorization, 4:95-104, 2013.

ANTUNES, L. F. S. et al. Production and efficiency of organic compost generated by millipede activity. Ciência Rural, 46(5):815-819, 2016.

ANTUNES, R. M. et al. Transformações químicas dos ácidos húmicos durante o processo de vermicompostagem de resíduos orgânicos. Engenharia Sanitária e Ambiental, 20(4):699-708, 2015.

BADDI, G. A. et al. Characterization of fulvic acids by elemental and spectroscopic (FTIR and 13C-NMR) analyses during composting of olive mill wastes plus straw. Bioresource Technology, 93(3):285-290, 2004.

BERNAL, M. P. et al. Maturity and stability parameters of composts prepared with a wide range of organic wastes. Bioresource Technology, 63(1):91-99, 1998.

BIANCHI, M. O.; CORREIA, M. E. Mensuração do consumo de material vegetal depositado sobre o solo por diplópode. Rio de Janeiro (BR): EMBRAPA Agrobiologia. 2007. 4p. (Embrapa Agrobiologia. Circular Técnica, 20).

BRAGANÇA, S. M. et al. Acumulação de matéria seca pelo cafeeiro conilon. Revista Ceres, 57(1):48-52, 2010.
BREMNER, J. M.; MULVANEY, C. S. Total nitrogen, in: PAGE, A. L. (Ed.), Methods of soil analysis. Madison (US): American Society of Agronomy, p. 595-624, 1982.

BUSWELL, J. A.; ODIER E. Lignin biodegradation. Critical Reviews in Biotechnology, 6(S1):1-60, 1995.

CASTALDI, P.; GARAU, G.; MELIS, P. Maturity assessment of compost from municipal solid waste through the study of enzyme activities and water-soluble fractions. Waste Management, 28(3):534-540, 2008.

CHANYASAK, V.; KUBOTA, H. Carbon/organic nitrogen ratio in water extract as measure of composting degradation. Journal of Fermentation Technology, 59:215-219, 1981.

CHAREST, M. H.; ANTOUN, H.; BEAUCHAMP, C. J. Dynamics of water-soluble carbon substances and microbial populations during the composting of de-inking paper sludge. Bioresource Technology, 91(1):53-67, 2004.

CIAVATTA, C. et al. Determination of organic carbon in aqueous extracts of soils and fertilizers. Communications Soil Science and Plant Analysis, 22(9-10):1467-1476, 1991.

COÛTEAUX, M. M.; ALOUI, A.; KURZ-BESSON, C. Pinus halepensis litter decomposition in laboratory microcosms as influenced by temperature and a millipede, Glomeris marginata. Applied Soil Ecology, 20(2):85-96, 2002.

DELMER, D. P.; AMOR, Y. Cellulose biosynthesis. The Plant Cell, 7(7):987-1000, 1995.

DEV, R.; ANTIL, R. S. Evaluation of maturity and stability parameters of composts prepared from agro-industrial wastes. Bioresource Technology, 102:2868-2873, 2011.

DIAS, B. O. et al. Use of biochar as bulking agent for the composting of poultry manure: Effect on organic matter degradation and humification. Bioresource Technology, 101(4):1239-1246, 2010.

DOMÍNGUEZ, J. et al. Vermicomposting grape marc yields high quality organic biofertiliser and bioactive polyphenols. Waste Management \& Research, 32:12351240, 2014.

DOMÍNGUEZ, J.; GÓMEZ-BRANDÓN, M. The influence of earthworms on nutrient dynamics during the process of vermicomposting. Waste Management \& Research, 31(8):859-868, 2013.

FARAH, A.; DONANGELO, C. M. Phenolic compounds in coffee. Brazilian Journal of Plant Physiology, 18(1):2336,2006 . 
FERNÁNDEZ-GÓMEZ, M. J. et al. Continuous-feeding vermicomposting as a recycling management method to revalue tomato-fruit wastes from greenhouse crops. Waste Management, 30(12):2461-2468, 2010.

GERASIMOVWICZ, W. V.; BAYLER, D. F. Carbon-13 CPMAS NMR and FTIR spectroscopic studies of humic acids. Soil Science, 139(3):270-278, 1985.

GRIGATTI, M.; CIAVATTA, C.; GESSA, C. Evolution of organic matter from sewage sludge and garden trimming during composting. Bioresource Technology, 91(2):163169, 2004.

HIRAI, M. F.; CHANYASAK, V.; KUBOTA, H. A standard method for measurement of compost maturity. Biocycle, 24:54-56, 1983.

HOPKIN, S. P.; READ, H. J. The biology of millipedes. Oxford (UK): Oxford University Press. 1992. 248p.

HUANG, G. F. et al. Transformation of organic matter during co-composting of pig manure with sawdust. Bioresource Technology, 97:1834-1842, 2006.

HUE, N. V.; LIU, J. Predicting compost stability. Compost Science \& Utilization, 3(2):8-15, 1995.

INBAR, Y.; CHEN, Y.; HADAR, Y. Humic substances formed during the composting of organic matter. Soil Science Society of America Journal, 54(5):1316-1323, 1990.

KALISZ, P. J.; POWELL, J. E. Effect of calcareous road dust on land snails (Gastropoda: Pulmonata) and millipedes (Diplopoda) in acid forest soils of the Daniel Boone National Forest of Kentucky, USA. Forest Ecology and Management, 186(1-3):177-183, 2003.

KARTHIGEYAN, M.; ALAGESAN, P. Millipede composting: A novel method for organic waste recycling. Recent Research in Science and Technology, 3(9):6267, 2011.

KOMILIS, D. P.; HAM, R. K. The effect of lignin and sugars to the aerobic decomposition of solid wastes. Waste Management, 23(5):419-423, 2003.

LOPEZ, M. J. et al. The effect of aeration on the biotransformation of lignocellulosic wastes by white-rot fungi. Bioresource Technology, 81(2):123-129, 2002.

MUPONDI, L. T.; MNKENI, P. N. S.; MUCHAONYERWA, P. Effects of a precomposting step on the vermicomposting of dairy manure-waste paper mixtures. Waste Management \& Research, 29(2):219-228, 2011.
NARDI, S. et al. Physiological effects of humic substances on higher plants. Soil Biology and Biochemistry, 34(11):1527-1536, 2002.

PARADELO, R. et al. Evolution of organic matter during the mesophilic composting of lingocellulosic winery wastes. Journal of Environmental Management, 116:18-26, 2013.

PARTHASARATHI, K. et al. Potential of Perionyxex cavatus (Perrier) in lignocellulosic solid waste management and quality vermifertilizer production for soil health. International Journal of Recycling Organic Waste in Agriculture, 5:65-86, 2016.

PLAZA, C. et al. Organic matter humification by vermicomposting of cattle manure alone and mixed with two-phase olive pomace. Bioresource Technology, 99(11):5085-5089, 2008.

RAMANATHAN, B.; ALAGESAN, P. Evaluation of millicompost versus vermicompost. Current Science, 103:140-143, 2012.

RAWLINS, A. J. et al. Stabilisation of soil organic matter in invertebrate faecal pellets through leaf litter grazing. Soil Biology and Biochemistry, 39(5):1202-1205, 2007.

RAWLINS, A. J. et al. The biochemical transformation of oak (Quercus robur) leaf litter consumed by the pill millipede (Glomeris marginata). Soil Biology and Biochemistry, 38:1063-1076, 2006.

SALGADO, P. R. et al. Total phenol concentrations in coffee tree leaves during fruit development. Scientia Agricola, 65(4):354-359, 2008.

SCHUBART, O. Novas espécies brasileiras da Familia Rhinocricidae (Diplopoda, Opisthos permophora). Anais da Academia Brasileira de Ciências, 34:69-87, 1962.

SEMENYUK, I. I.; TIUNOV, A. V.; GOLOVATCH, S. I. Structure of mandibles in relation to trophic niche differentiation in a tropical millipede community. International Journal of Myriapodology, 6:37-49, 2011.

SRIDHAR, K. R.; AMBARISH, C. N. Pill millipede compost: A viable alternative to utilize urban organic solid waste. Current Science, 104(11):1543-1547, 2013.

STEVEnSON, F. J. Humus Chemistry: Genesis, Composition Reactions. New York (US): WileyInterscience. 1994. 512p.

SUBHEDAR, P. B.; GOGATE, P. R. Alkaline and ultrasound assisted alkaline pretreatment for intensification of delignification process from sustainable raw-material. Ultrasonics Sonochemistry, 21(1):216-225, 2014. 
SVYRYDCHENKO, A. O.; BRYGADYRENKO, V. V. Trophic preferences of Rossiulus kessleri (Diplopoda, Julidae) for the litter of various tree species. Folia Oecologica, 41(2):202-212, 2014.

TAHERZADEH, M. J.; KARIMI, K. Pretreatment of lignocellulosic wastes to improve ethanol and biogas production: A review. International Journal of Molecular Sciences, 9(9):1621-1651, 2008.

TAJOVSKÝ, K. et al. Decomposition of faecal pellets of the millipede Glomeris hexasticha (Diplopoda) in forest soil. Pedobiologia, 36(3):146-158, 1992.

TAYLOR, E. C.; CRAWFORD, C. S. Microbial gut symbionts and desert detritivores. Arid Zone Research, 1:37-52, 1982.

TEDESCO, M. J. et al. Análise de solo, plantas e outros materiais. 2nd ed. Porto Alegre (BR): UFRGS. 1995. $174 \mathrm{p}$.

TORTOSA, G. et al. The production of commercial organic amendments and fertilisers by composting of two-phase olive mill waste ("alperujo"). Journal of Cleaner Production, 26:48-55, 2012.

UNITED STATES DEPARTMENT OF AGRICULTURE USDA. Departament of agriculture, soil survey staff. Web Soil Survey, Natural Resources Conservation Service. USDA. Available in: http:<//websoilsurvey.nrcs.usda. gov.> Access in: 2020.

URBASEK, F.; TAJOVSKÝ, K. The influence of food and temperature on enzymatic activities of the millipede
Glomeris hexasticha (Diplopoda). Revue d'Ecologie et de Biologie du Sol, 28(2):155-163, 1991.

VAN SOEST, P.; WINE, R. H. Development of a comprehensive system of feed analysis and its applications to forages. Journal of Agricultural and Food Chemistry, 51:780-785, 1968.

WALKLEY, A.; BLACK, I. A. An examination of the Deytjareff method for determining soil organic matter and a proposed modification of the chromic acid titration method. Soil Science, 37(1):29-38, 1934.

WU, L.; MA, L.; MARTINEZ, G. Comparison of methods for evaluating stability and maturity of biosolids compost. Journal of Environmental Quality, 29(2):424-429, 2000.

YAMADA, Y.; KAWASE, Y. Aerobic composting of waste activated sludge: Kinetic analysis for microbiological reaction and oxygen consumption. Waste Management, 26(1):49-61, 2006.

YAN, Z. et al. The effects of initial substrate concentration, $\mathrm{C} / \mathrm{N}$ ratio, and temperature on solid-state anaerobic digestion from composting rice straw. Bioresource Technology, 177:266-273, 2015.

ZHOU, Y. et al. Evaluation of humic substances during co-composting of food waste, sawdust and Chinese medicinal herbal residues. Bioresource Technology, 168:229-234, 2014.

ZMORA-NAHUM, S. et al. Dissolved organic carbon (DOC) as a parameter of compost maturity. Soil Biology Biochemistry, 37(11):2109-2116, 2005. 